\title{
Planktonic larvae of the rare spoon worm, Ikedosoma elegans (Annelida: Thalassematidae), collected from Tanabe Bay, Wakayama, Japan
}

\author{
Keisuke Koizumi $^{1, *}$, Tomoyuki NaKano ${ }^{1,2} \&$ AkiRA Asakura ${ }^{1,2}$ \\ ${ }^{1}$ Department of Zoology, Division of Biological Science, Graduate School of Science, Kyoto University, \\ Kitashirakawa Oiwake-cho, Sakyo-ku, Kyoto 606-8502, Japan \\ ${ }^{2}$ Seto Marine Biological Laboratory, Field Science Education and Research Center, Kyoto University, \\ 459 Shirahama, Wakayama 649-2211, Japan
}

Received 10 November 2020; Accepted 11 February 2021 Responsible Editor: Shinji Shimode

doi: $10.3800 /$ pbr. 16.149

\begin{abstract}
Human activities, such as coastline development, water pollution, and the introduction of invasive species, threaten mudflat macrofauna. Many spoon worm species are endangered, possibly because of anthropogenic disturbance of mudflat environments. Understanding worm ecology is necessary for conservation. However, information regarding these species is limited, presumably because of difficulties in sample collection. In Tanabe Bay, Wakayama Prefecture, Japan, we attempted to collect and identify planktonic larvae instead of adults, using DNA barcoding to determine rare species. A larva of the rare spoon worm, Ikedosoma elegans, endemic to Japan, was collected. Thus, the existence of an unknown population of I. elegans likely exists. Furthermore, the use of larval monitoring for detecting rare marine invertebrates is demonstrated.
\end{abstract}

Key words: DNA-barcoding, Thalassematidae, meroplankton, larval biodiversity, mudflats

Mudflats provide productive habitats for diverse macrofauna communities that utilize sediment nutrients (Van Colen 2018). Burrowing species, such as decapod crustaceans, polychaetes, or thalassematids, are especially important as ecosystem engineers through bioturbation (Volkenborn et al. 2007) and by providing habitat for smaller species (e.g., Anker et al. 2005, McDermott 2005, Henmi \& Itani 2014). Mudflats are heavily affected by anthropogenic activities, such as coastline development, water pollution, and the introduction of invasive species (Henmi 2012, Passarelli et al. 2018). Because of the reduction and alteration of habitats, many mudflat macrobenthos are endangered, including several thalassematid species (Japanese Association of Benthology 2012). In these mudflat thalassematids, however, present conservation status is not sufficiently understood, because of the lack of distribution records (Nishikawa 2012).

Thalassematids, or spoon worms, are benthic marine worms that live exclusively in marine or brackish water

*Corresponding author: Keisuke Koizumi; E-mail, koizumi.keisuke. 53c@st.kyoto-u.ac.jp
(Brusca et al. 2016). They were formerly known as echiurans and now are considered to be annelids (Goto et al. 2020). Most thalassematids burrow in the sand or mud or live in surface detritus or rubble (Brusca et al. 2016). Research regarding deep-burrowing thalassematids is often scarce because of difficulties in collecting adult specimens (Oshiro et al. 2020). However, thalassematid larvae remain planktonic for up to 3 months (Pilger 1978), and monitoring of rare planktonic larvae may provide clues for the existence of an adult population. We collected planktonic larvae from plankton net samples and identified them using DNA barcoding to evaluate unknown benthic diversity.

We collected larval samples in Tanabe Bay from the research vessel Zoea, owned by Seto Marine Biological Laboratory, Kyoto University, on August 27, 2019. The sampling point was located at the entrance of Tanabe Bay (Fig. 1). Plankton samples were collected through vertical haulings from the bottom layer using a North Pacific Standard (NORPAC) net with a mesh size of NMG52 (0.335 mm). Water temperature and salinity were measured simultaneously with a Compact-CTD (ALEC). Samples were sorted 


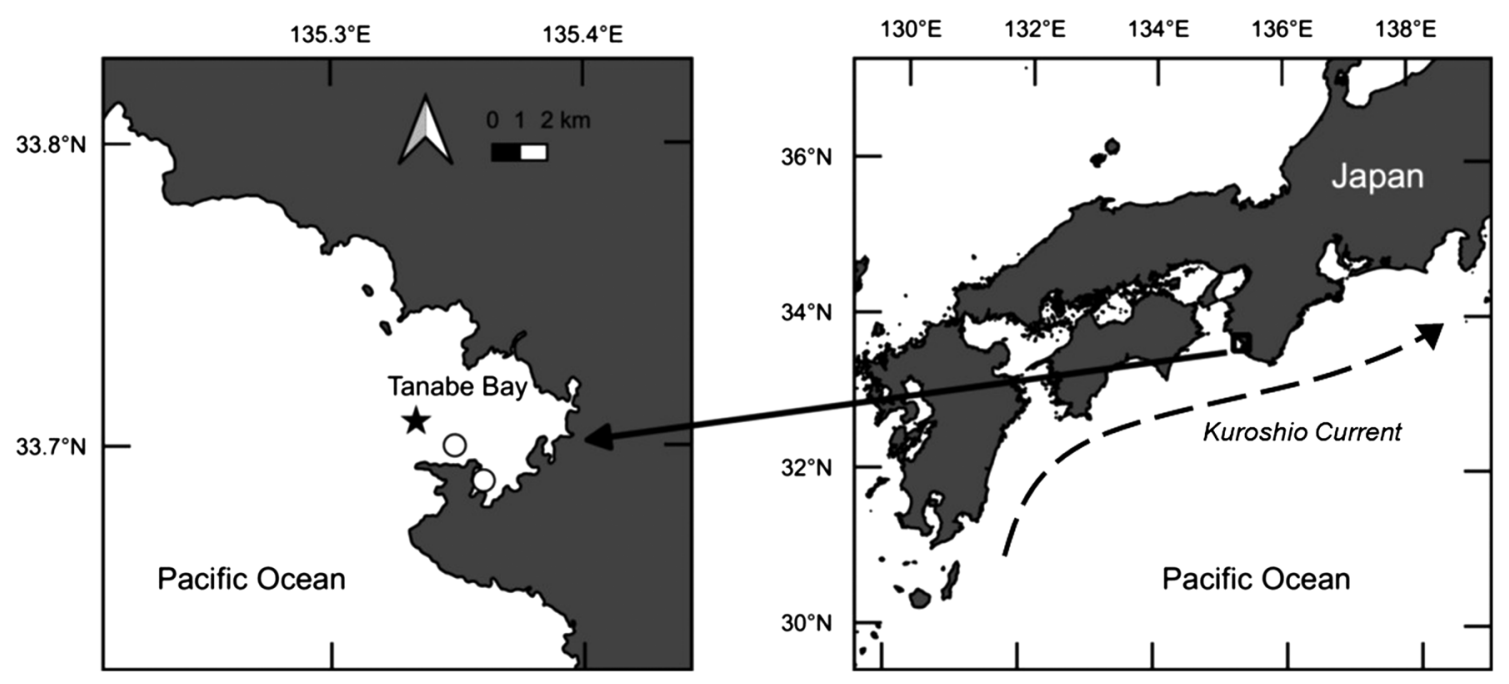

Fig. 1. Locations of sampling stations in Tanabe Bay, Wakayama Prefecture. Star: the sampling station where the larva of Ikedosoma elegans was collected. Circles: other sampling stations. Dashed line with an arrow: typical current pattern of the Kuroshio Current (Yoshida 1964).

Table 1. Accession numbers of the specimens used in this study. PL-1264: the sample number of the collected larva.

\begin{tabular}{lccc}
\hline \multicolumn{1}{c}{ Species } & Voucher & Accession number & Sources \\
\hline PL-1264 (Larval sample) & - & LC586019.1 & This study \\
Ikedosoma elegans & NSMT-Ec 113 & AB968023.1 & Tanaka et al. (2014) \\
& NSMT-Ec 114 & AB968024.1 & Tanaka et al. (2014) \\
Ikedosoma gogoshimense & NSMT-Ec 133 & AB968026.1 et al. (2014) & Tanaka et al. (2014) \\
& NSMT-Ec 154 & AB968027.1 & Tanaka et al. (2014) \\
NSMT-Ec 138 & AB968029.1 et al. (2014) \\
Listriolobus sorbillans & NSMT-Ec 116 & AB968031.1 & Tanaka et al. (2014) \\
& & & Tanaka et al. (2014)
\end{tabular}

under a SMZ1500 stereomicroscope (Nikon) and photographed using an EOS Kiss X9i camera (Canon) with a NY-CZ microscope attachment (MICRONET). Sorted larvae were fixed in $99 \mathrm{wt} \%$ ethanol and stored in $1.5 \mathrm{~mL}$ microtubes. From these collections we identified a thalassematid larva from the entrance of Tanabe Bay, Wakayama Prefecture, Japan.

Morphological features of the larva were observed from photographs taken before DNA extraction. Larvae were transferred into sterile $1.5 \mathrm{~mL}$ microtubes, and whole DNA was extracted using a High Pure PCR Template Preparation Kit (Roche). A partial cytochrome c oxidase subunit I (COI) gene was amplified via PCR with primers LCO1490 (5'-GGT CAA CAA ATC ATA AAG ATA TTG G-3') and HCO2198 (5'-TAA ACT TCA GGG TGA CCA AAA AAT CA-3') (Folmer et al. 1994). Each PCR reaction was $15 \mu \mathrm{L}$ consisting of EmeraldAmp Mix (Takara), $7.5 \mu \mathrm{L}$ each; $5 \mu \mathrm{M}$ primer primers, $0.6 \mu \mathrm{L}$ each primer; $1 \mu \mathrm{L}$ Template DNA; and volume made up with $\mathrm{dH} 2 \mathrm{O}$. The PCR reaction included initial denaturation at $94^{\circ} \mathrm{C}$ for $3 \mathrm{~min}$, followed by 35 cycles of $94^{\circ} \mathrm{C}$ for $30 \mathrm{~s}, 45^{\circ} \mathrm{C}$ for $60 \mathrm{~s}, 72^{\circ} \mathrm{C}$ for $60 \mathrm{~s}$, and a final extension at $72^{\circ} \mathrm{C}$ for $5 \mathrm{~min}$. PCR success was checked via electrophoresis on $1 \%$ agarose gel, and successfully amplified PCR products were purified using High Pure PCR Product Purification Kit (Roche). DNA sequences were consigned to Eurofins Genomics Inc. We assembled sequence data using GeneStudio 2.2.0.0 (GeneStudio Inc.) and searched for similar sequences with an NCBI Blast web search. Furthermore, we constructed a maximum likelihood tree with retrieved sequences and GenBank sequences of closely related species, as evaluated from BLAST results (Table 1). The phylogenetic tree was constructed using MEGA X (Kumar et al. 2018) with a GTR $+\mathrm{G}+\mathrm{I}$ model.

One trochophore larva (Fig. 2A) was identified as Ikedosoma elegans (Ikeda 1904) using the BLAST search. PCR recovered a 653 bp partial CO1 gene sequence (accession No. LC586019.1) from the unknown larva that had its highest BLAST identity score with I. elegans (accession No. AB968024.1). The query cover rate and percent identity were $99 \%$ and $99.54 \%$, respectively. The retrieved sequence through the construction of an ML tree was mono- 


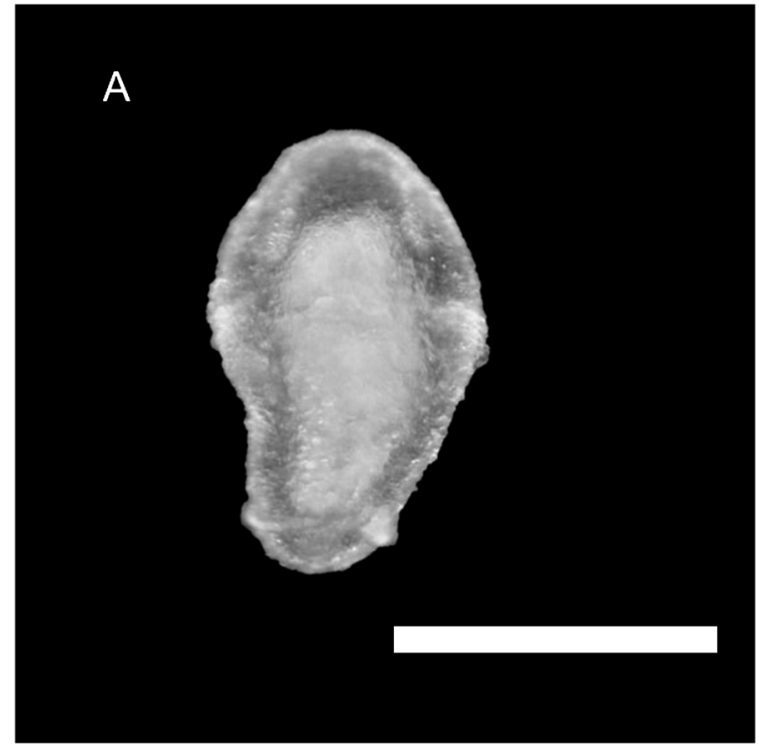

B

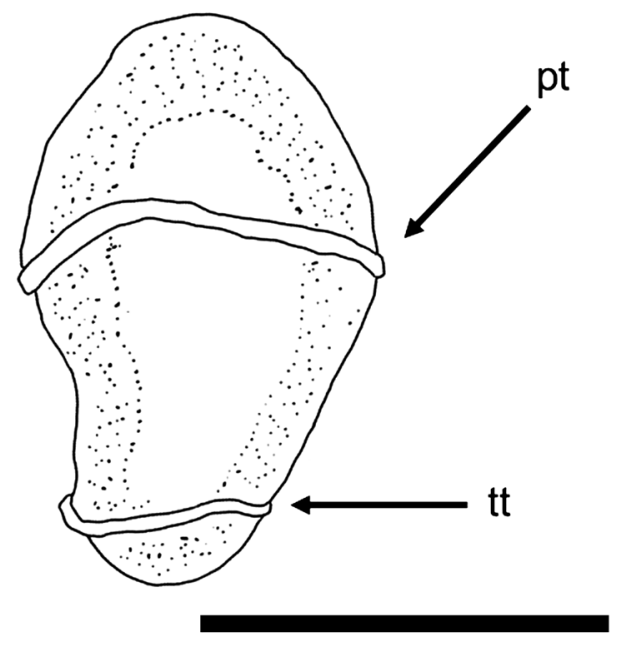

Fig. 2. A: Photograph and B: Sketch of the collected larval sample. Scale bar: $0.5 \mathrm{~mm}$. pt: prototroch. tt: telotroch.

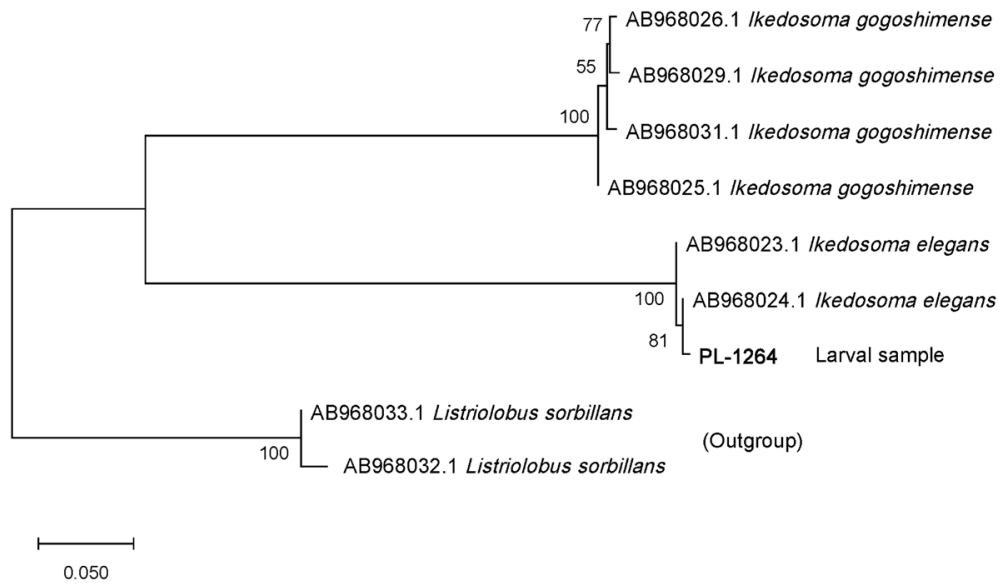

Fig. 3. Maximum-likelihood phylogenetic tree based on the COI sequence of the larval sample and closely related species from GenBank. PL-1264: the sample number of the collected larva. Bootstrap support values are shown at respective nodes. The scale bar represents the number of substitutions per site.

Table 2. The genetic distance (K2P) values based on the COI sequences of the larval sample and other Ikedosoma sequences from GenBank. PL-1264: the sample number of the collected larva.

\begin{tabular}{clccccc}
\hline No. & \multicolumn{1}{c}{ Sample Name } & 1 & 2 & 3 & 4 & 5 \\
\hline 1 & PL-1264 (Larval sample) & - & & & & \\
2 & AB968024.1 Ikedosoma elegans & 0.01082 & - & & & \\
3 & AB968023.1 Ikedosoma elegans & 0.01434 & 0.00918 & - & & \\
4 & AB968025.1 Ikedosoma gogoshimense & 0.28897 & 0.28648 & 0.28457 & - & - \\
5 & AB968026.1 Ikedosoma gogoshimense & 0.30113 & 0.28377 & 0.28775 & 0.00953 & -0.00809 \\
6 & AB968029.1 Ikedosoma gogoshimense & 0.28590 & 0.28336 & 0.28193 & 0.01138 & 0.01125 \\
7 & AB968031.1 Ikedosoma gogoshimense & 0.28898 & 0.28647 & 0.28537 & 0.01124 & 0.01138 \\
\hline
\end{tabular}

phyletic with other I. elegans sequences from GenBank (Fig. 3), and genetic differences were small enough to be considered as intraspecific; $1.1 \%$ and $1.4 \%$ genetic distance were calculated using MEGA $\mathrm{X}$ under a Kimura two- parameter model (Table 2).

The larva was collected from the entrance of Tanabe Bay (the star on Fig. 1, 334ㄴ $22^{\prime \prime} \mathrm{N}$; 135 $20^{\prime} 1^{\prime \prime} \mathrm{E}$, depth $20 \mathrm{~m})$. The averages of temperature and salinity of its sam- 
pling station were $23.9 \pm 1.4^{\circ} \mathrm{C}, 33.3 \pm 2.8$, respectively.

The larva was approximately $720 \mu \mathrm{m}$ in length and $470 \mu \mathrm{m}$ in width. An apparent prototroch, typical of trochophore larvae, was observed on the midsection of the body (Fig. 2B). Furthermore, a telotroch was observed near the posterior of the larva, a typical feature of larvae of some polychaetes and thalassematids (Rouse 1999). The collected larva was similar in size and shape to 30 day larvae of Ikedosoma gogoshimense (Ikeda 1904), as reported from laboratory-fertilized and raised specimens by Sawada and Ochi (1962).

Evidence from larval morphology and CO1 sequences leads us to conclude that the larval specimen is I. elegans. Ikedosoma elegans is a rare endemic thalassematid in Japan. The species inhabits mudflats by constructing U-shaped burrows approximately $120 \mathrm{~cm}$ into the substrate (Ikeda 1904, 1907), as recorded from the Miura Peninsula (Ikeda 1904, Tanaka et al. 2014), Okayama Prefecture (Tanaka et al. 2014), Lake Hamana (Tanaka et al. 2014), the Boso Peninsula (Komai 2015), and possibly from the Amakusa Islands (Komai 2015, Goto et al. 2018). No records of I. elegans from the coast of the Kii Peninsula exist. Its rarity and limited distribution are the basis for its designation as a near-threatened species (Nishikawa 2012; Ministry of Environment 2017), or data deficient (Tanaka $\&$ Sato 2019). Correct evaluation of status and effective conservation requires information concerning its present habitat. The identification of the larva suggests unknown habitat for I. elegans near Tanabe Bay. Several possible habitats for the species exist around Tanabe Bay, such as the mudflats at Torinosu and Uchinoura located along the inner part of the bay. Mudflat environments in both locations are recovering, and occurrences of several rare species have been recorded (Koga et al. 2018). However, several thalassematids display extended planktonic larval periods, and no larvae were collected from the inner bay. Therefore, the larva may have drifted from a distant habitat. Habitat for I. elegans may occur upstream along the Kuroshio Current (Fig. 1; the dashed line), along the Pacific coast of Kyushu and Shikoku. However, no published records of the species from these locations exist. In any case, the present observation suggests the presence of one or more unknown populations of I. elegans. A survey of possible habitats is urgently needed to initiate conservation.

Planktonic larvae are often small and lack characteristic features, making species-level identification difficult from morphology alone. DNA barcoding enabled us to identify the larva, and the identification provided unique information about a rare endemic species. Monitoring of planktonic larvae using DNA barcoding will be useful for detecting the existence of marine invertebrates that are difficult to collect as adults. Metabarcoding of environmental DNA, established recently (Ruppert et al. 2019), may also be effective for detecting such species. The availability of numerous and correctly identified reference sequences is important to maximize efficiency.

\section{Acknowledgements}

We thank Hiroki Yamauchi and Kohki Yamamoto for their help in collecting materials. This study was partly supported by the Link Again Program of the Nippon Foundation-Kyoto University Joint Project. The authors would like to thank Enago (www.enago.jp) for the English language review.

\section{References}

Anker A, Murina GV, Lira C, Vera Caripe JA, Palmer AR, Jeng MS (2005) Macrofauna associated with echiuran burrows: A review with new observations of the innkeeper worm, Ochetostoma erythrogrammon Leuckart and Rüppel, in Venezuela. Zool Stud 44: 157-190.

Brusca RC, Moore W, Schuster M (2016) Invertebrates, Third Edition. Sinauer Associates, Sunderland, Massachusetts, 1104 pp.

Folmer O, Black M, Hoeh W, Lutz R, Vrijenhoek R (1994) DNA primers for amplification of mitochondrial cytochrome $\mathrm{c}$ oxidase subunit I from diverse metazoan invertebrates. Mol Mar Biol Biotech 3: 294-299.

Goto R, Henmi Y, Corral JM, Shiozaki Y, Kato T, Itani G (2018) First record of the rare spoon worm Ikedosoma elegans (Annelida: Echiura: Thalassematidae) from Shikoku Island, Japan. Japan J Benthol 72: 79-82. (in Japanese)

Goto R, Monnington J, Sciberras M, Hirabayashi I, Rouse GW (2020) Phylogeny of Echiura updated, with a revised taxonomy to reflect their placement in Annelida as sister group to Capitellidae. Invertebr Syst 34: 101-111.

Henmi Y (2012) Present status of Japanese tidal flats. In: Threatened Animals of Japanese Tidal Flats: Red Data Book of Seashore Benthos. (eds Japanese Association of Benthology). Tokai University Press, Hatano, pp. 2-6. (in Japanese)

Henmi Y, Itani G (2014) Burrow utilization in the goby Eutaeniichthys gilli associated with the mud shrimp Upogebia yokoyai. Zool Sci 31: 523-528.

Ikeda I (1904) The Gephyrea of Japan. J Coll Sci Imp Univ Tokyo 20: 1-87.

Ikeda I (1907) On three new and remarkable species of echiuroids (Bonellia miyajimai, Thalassema taenioides and $T$. elegans). J Coll Sci Imp Univ Tokyo 21: 1-64.

Japanese Association of Benthology (2012) Threatened Animals of Japanese Tidal Flats: Red Data Book of Seashore Benthos. Tokai University Press, Tokyo, 285 pp. (in Japanese)

Koga T, Aoki M, Kohda Y, Watanabe T (2018) Temporal change in the tideland macrobenthos in Tanabe Bay: based on the Monitoring 1000 Project. Bull Kansai Org Nat Cons 40: 129141. (in Japanese)

Komai T (2015) A new species of the snapping shrimp genus $\mathrm{Al}$ pheus (Crustacea: Decapoda: Caridea: Alpheidae) from Japan, associated with the innkeeper worm Ikedosoma elegans (Annelida: Echiura: Echiuridae). Zootaxa 4058: 101-111.

Kumar S, Stecher G, Li M, Knyaz C, Tamura K (2018) MEGA $\mathrm{X}$ : Molecular evolutionary genetics analysis across computing platforms.Mol Biol Evol 35: 1547-1549.

McDermott JJ (2005) Biology of the brachyuran crab Pinnixa 
chaetopterana Stimpson (Decapoda: Pinnotheridae) symbiotic with tubicolous polychaetes along the Atlantic coast of the United States, with additional notes on other polychaete associations. Proc Biol Soc Wash 118: 742-764.

Ministry of Environment (2017) Publication of the Red List for marine organisms, the version of the Ministry of the Environment. Available at: https://www.env.go.jp/press/103813.html (accessed on 1 Sep 2020). (in Japanese)

Nishikawa T (2012) Phylum Echiura. In: Threatened Animals of Japanese Tidal flats: Red Data Book of Seashore Benthos. (eds Japanese Association of Benthology). Tokai University Press, Hatano, pp. 235-238.

Oshiro K, Hirabayashi I, Henmi Y, Goto R (2020) Records of the giant spoon worm Ikeda taenioides (Annelida: Echiura: Ikedidae) from the Kii Peninsula, the Sea of Japan, and AmamiOshima Island. Japan. Japan J Benthol 74: 93-97. (in Japanese)

Passarelli C, Hubas C, Paterson DM (2018) Mudflat Ecosystem Engineers and Services. In: Mudflat Ecology. (eds Beninger PG). Springer, Chicago. pp. 243-269.

Pilger J (1978) Settlement and metamorphosis in Echiura: A review. In: Settlement and Metamorphosis of Marine Invertebrate Larvae. (eds Chia FS, Rice ME). Elsevier, New York, pp. 103-112.

Rouse GW (1999) Trochophore concepts: Ciliary bands and the evolution of larvae in spiralian Metazoa. Biol J Linn Soc Lond 66: 411-464.

Ruppert KM, Kline RJ, Rahman MS (2019) Past, present, and fu- ture perspectives of environmental DNA (eDNA) metabarcoding: A systematic review in methods, monitoring, and applications of global eDNA. Glob Ecol Conserv 17: e00547.

Sawada N, Ochi O (1962) Studies on the fertilization in eggs of echiuroid, Ikedosoma gogoshimense (Ikeda) 1. An outline of the fertilization and the development. Mem Ehime Univ SectII SerB 4: 551-561. (in Japanese)

Tanaka M, Kon T, Nishikawa T (2014) Unraveling a 70-year-old taxonomic puzzle: redefining the genus Ikedosoma (Annelida: Echiura) based on morphological and molecular analyses. Zool Sci 31: 849-861.

Tanaka M, Sato M (2019) Phylum Annelida. Okayama Prefecture Wildlife Species List. Available at: https://www.pref.okayama. jp/uploaded/life/657114_5706590_misc.pdf (accessed on 15 Sep 2020). (in Japanese)

Van Colen C (2018) The Upper Living Levels: Invertebrate Macrofauna. In: Mudflat Ecology. (eds Beninger PG). Springer, Chicago. pp. 149-168.

Volkenborn N, Hedtkamp SIC, van Beusekom JEE, Reise K (2007) Effects of bioturbation and bioirrigation by lugworms (Arenicola marina) on physical and chemical sediment properties and implications for intertidal habitat succession. Estuar Coast Shelf Sci 74: 331-343.

Yoshida S (1964) A note on the variations of the Kuroshio during recent years. Bull Jpn Soc Fish Oceanogr 5: 66-69. (in Japanese) 